\title{
EQUILIBRIUM
}

Quarterly Journal of Economics and Economic Policy

VOLUME 7 ISSUE 1, 2012

ISSN 1689-765X

\author{
Małgorzata Dolińska* \\ University of Maria Curie-Sktodowska \\ in Lublin, Poland
}

\section{Activity of Companies IN INNOVATION NETWORKS}

\section{JEL Classification Codes: 031}

Keywords: innovation process, innovation network, company

\begin{abstract}
Innovation networks can be understood as an organization in which two or more independent firms aim at joint research, development or spreading of innovations. In such a relatively stable and cooperative collaboration, the partner firms find support during one or more activities of the innovation process, which may increase their innovation performance. Relationships of innovative companies with partners in networks are based on development and transfer knowledge, which is used in innovation processes. With development of innovations in the network, knowledge and other resources are multiplied. The objective of this work is to explore cooperative relationships of companies with partners during innovation process execution within the network's framework. This paper analyzes the impact of these relationships on the development of innovative companies, as well as also attempts to describe synergy effects of cooperation between partners in innovation networks. Questionnaire research on this subject was conducted in Lubelskie region in 2009. Summary results of these research are described in this work.
\end{abstract}

(C) Copyright Nicolaus Copernicus University Press

Date of Submission: March 1, 2011; date of acceptance: October 10, 2011

* Contact: e-mail: m.dolinska@umcs.lublin.pl, Uniwersytet Marii Curie-Skłodowskiej w Lublinie, Pl. Marii Curie-Skłodowskiej 5, 20 - 031 Lublin, Poland 


\section{INTRODUCTION}

Innovation results from continuing interactions and relationships between different actors and organizations which cooperate and compete between each other during execution of innovation process activities in the network. The function of innovation is to introduce novelty (variety) into the economic sphere. Innovation is crucial for long-term economic growth.

Innovation can refer to new products/services, improved production/business processes or new solutions in the area of management (finance, marketing, and/or human resources). Technological innovations, which derive from research, comprise the implementation of technologically new products and processes and also significant technological improvements in products and processes. An innovation has been implemented if it has been introduced on the market (product innovation) or used within a production or business process (Dolińska 2006, p. 41; Pomykalski 2001, pp. 17-18).

Innovations are knowledge products resultant from the execution of innovation processes. The innovation process consists of the following activities: development of a new solution concept, innovation elaboration, its application, promotion and selling on the innovation market, and also its improvement at all times. The completion of any stage of an innovation process is considered to be an innovative solution which can be offered for sale on the market. During the course of the process interactions and relations are shaped among its contractors connected with the flow, application, and development of shared knowledge and information. This, in turn, becomes a source of new innovative solutions and their diffusion. Innovation processes entail knowledge sharing and development, learning of associated companies which cooperate with one another in the network in exploiting their resources (Dolińska 2010, p. 8).

A central finding in innovation literature is that a firm does not innovate in isolation, but depends on extensive interaction with its environment. Various concepts have been introduced to enhance our understanding of this phenomenon, most of them including the term "network" (Fagerberg 2006, p. 20).

Our goal in this paper is to assess the results of research on the role of networks in the innovation processes which were carried out by innovative companies of Lubelskie region. The study focused on the evaluation of cooperation between companies and their partners in innovation networks, both at home and abroad, including the following partners: companies in the same line of business, operating in other areas, R\&D entities, innovation transfer institutions, technological and science parks, clusters, regional 
bodies of authority (including those abroad), local authorities, and other business entities.

\section{DEVELOPMENT OF INNOVATIONS IN THE NETWORK}

Networks are understood as a mode of organization which legally independent companies voluntarily chose over hierarchical or market modes of organization by establishing flexible ties and sharing collective assets among each other, in order to sustain or strengthen their competitive position (Dilk, Gleich, Wald 2008, p. 693). Networks are viewed as structures of inter-firm relationships that emerge and evolve through continuous interactive processes. Much of the change in the network is regarded as originating from the network process - the connecting of actor bonds, activity links and resource ties in interaction between companies (Halinen, Törnroos 1998, pp. 187, 190) and their partners. Networks are dynamic and constantly changing, flexible structures of organizations.

Today's companies are faced with dynamic and turbulent environment that requires flexible and fast responses to growing competition on markets and changing consumers' needs, and expectations. Many of them have responded by taking part in innovation process execution in decentralized, team-based, and distributed, constantly changing structures as networks (also cluster, technology and science parks). Companies must partner effectively with other organizations and institutions in the innovation area in order to form a competitively superior value-delivery network on the innovation market.

Flexibility allows the network organization to react quickly to unexpected situations (Basadur, Gelade 2006, p. 45) and changes on the market, and also create and exploit effectively knowledge of their partners during innovation process execution.

Innovation arises from complex interactions and relationships between individuals, firms-partners of the network organization and their operating environment during the implementation of innovation processes. The knowledge and learning capacities of people and companies are instrumental for innovation processes, as are their powers of creativity, initiative and drive, determining, to a large extent, the innovation capacity of network organization and its partners, and also knowledge using efficiency in innovations. The role of interactions and relationships between partners of innovation network is central to knowledge creation, transfer and effective using in innovation processes. 
Increasingly, innovations have come to be based on the interactions and relationships forming during knowledge, and information flow between economic entities such as firms (partners, suppliers, competitors and their consumers), research organizations (high school, universities, polytechnics, other public and private research and development institutions), public agencies (innovation transfer centers, development agencies, industry or science and technology parks), finance institutions (innovation financial support: venture capital, funds, and loans) and regional and/or local authorities. These entities may collaborate among themselves as partners of a network organization during the execution of innovation process activities.

Networks are critical not only for accessing knowledge to create inhouse innovations, or for the diffusion of technological ones, but they are equally important for learning about innovative work practices that other organizations have developed or adopted. They influence it in a number of ways. First, by enhancing companies' access to knowledge - promoting awareness and early adoption of innovations - and, secondly, by promoting social interaction, generating trust and reciprocity that is conducive to knowledge transfer (Pittway, Robertson, Munir, Deneyer, Neely 2004, p. 145).

Innovation, the effect of the development and application of knowledge in the network now determine its economic success in a knowledge-based economy. The value of the organisation in this economy depends on evergrowing inside and outside resources of the company knowledge, exchange of knowledge with partners during accomplishing of innovation processes, and also its effective application in innovative offers addressed to customers.

Networks may be differentiated with respect to their duration and stability, as well as whether they are forged to accomplish a specific task or evolve out of pre-existing bonds of association. Networks vary from shortterm projects to long-term relationships, and the different temporal dimensions have important implications for others are more heterarchical, with distributed authority and strong self-organizing features. Powell focuses on temporal stability and forms of governance to differentiate four key types: informal networks (based on shared experience - for instance a club of innovators); project networks (short-term combinations to accomplish specific tasks - application of new technology); regional network (where spatial propinquity helps sustain a common community - collaboration of firms with $R \& D$ institutions and universities, polytechnics in the region); and business networks (purposive, strategic alliances between two or more parties - science and technology park, cluster) (Powell 2004, p. 39). 
Additionally, there is a wide range of potential network partners, e.g. suppliers, customers, competitors or organizations from other industries. By differentiating between horizontal, vertical and lateral relationships, it is possible to make a distinctive classification of innovation networks. In this terminology, a vertical innovation networks is a cooperation between several companies along their common supply chain. Often, these companies are direct competitors, implying a so-called co-opetition arrangement. Furthermore, cooperation between a firm and other organizations that are not permanently linked in a direct economic sense can be denominated as a lateral innovation network. For example, it can be thought of networks between scientific institutes or universities and companies or the transfer of knowledge, innovations across the boundaries of distinctive industries whose sales markets do not compete and interrelate with each other (Dilk, Gleich, Wald 2008, p. 694).

The role of third parties, such as professional associations, trade associations and publicity funded bodies specifically aimed at promoting innovation (such as technology transfer centers) have a positive impact on the development of inter-organizational networks and innovation. Third parties have a dual role in promoting innovation. They ideally act as neutral knowledge brokers but also act as important conduits for the development of informal relationships (personal relations between individuals), which are the basis for the development of network relationships, particularly between small firms. Although professional associations, trade associations and consultants make some important contributions to the network infrastructure, they are one of many network mechanisms that improve regional infrastructures. Science partners (categorized as universities, technical colleges, research institutes, applied science consultancies and independent research and design laboratories) also all play an important role within the network infrastructure (Pittway, Robertson, Munir, Deneyer, Neely 2004, p. 154).

Every country should construct open innovation systems (of country and its regions), which not only focus on the participated public and private sectors but also expand to relative economic structure, and various social cooperation networks that help effectively improve collective learning and knowledge innovation. A country's capability to produce and innovate can be improved by an increasing number of well skilled and educational employees (Chen 2008, pp. 501, 507) and also their interactions and relationships inside and outside the companies during execution of innovation processes in the network.

For organizations in rapidly developing fields, heterogeneity in the portfolio of collaborators allows firms to learn from a wide stock of knowledge. Organizations with broader networks are exposed to more experiences, 
different competences, and added opportunities. By having access to a more varied set of activities, experiences, and collaborators, companies broaden the resource and knowledge base that they can draw on (Powell, Grodal 2006, p. 59). These possibilities enable them to develop faster and build competitive position on the innovation market.

This paper's focus lies on interactions and relationships of the innovative company with partners of the innovation network. They are formed during execution of innovation processes by the following partners of the network and its employees:

- Partner entities of the national and the regional systems of innovation;

- Companies and their customers and/or suppliers/distributors of knowledge, information, innovative solutions (also patents, licences),

- Employees and project or process teams which cooperate with each other in the company and with the partner entities of the innovation networks (also regional innovation systems): firms in the same and/or different lines of business, $R \& D$ institutions, laboratories, high schools, universities, polytechnics, technology and science parks, clusters, regional and/or local authorities, innovation transfer institutions, clubs of innovators, associations of innovators, suppliers of funds for innovations, consulting firms, innovation sale and promotion services.

Relationships of innovative companies with partners in networks are based on development and transfer of knowledge which is used in innovation processes. Good partner relationships are at the heart of the company success in the network and its innovative offer on the market. Intangible assets such as relationships with partners and supply channels are defined as relational market-based capital of a company which can provide sustainable competitive advantage and added value for a company, and its partners, particularly in innovation area.

The most important goals that the innovative companies aim to realize by using innovation networks include flexible access to and acquiring technologies, new solutions and also current knowledge, intensified contact with clients, partners, access to and entering new markets, long-term bonding of knowledge suppliers and clients, safeguarding the network members (partner-firms) from outside competition on the innovation market, access to other innovative competencies, results of $R \& D$, reducing $R \& D$ time and costs, increasing efficiency of innovation process accomplishment, access to many sources of innovation financing and flexible using of them during innovation development and application.

An empirical survey was able to confirm that innovation networks are of high relevance in the innovation area. It can be expected that innovation networks will spread further and gain more importance in the coming years. 


\section{QUESTIONNAIRE RESEARCH ON ROLE NETWORKS IN DEVELOPMENT OF INNOVATIVE COMPANIES}

The study was conducted among respondents from 64 innovative companies of the Lubelskie Voivodeship in 2009 (Dolińska 2009). We had considered innovative companies to be the most suitable population on which to carry out the empirical study. The research sample was chosen as nonprobability, judgment sample of companies. The selection of the representative sample was based on the criterion of their activity, i.e. $50 \%$ of industrial processing companies and $50 \%$ of this number was made up by service providers. The questionnaire respondent was the manager of the firm with the necessary knowledge and perspective to answer all the questions.

The objectives of the questionnaire research were to examine:

- whether Lubelskie region companies cooperate with partners during innovation process execution in the network,

- with what partners companies collaborate in innovation processes

For the purpose of this survey, the following research hypothesis was made:

Cooperation of companies with partners generates a synergy effect during the execution of innovation process activities within the framework of the network.

The breakdown of the analysed companies structure by size was as follows: $25 \%$ were micro-, $34,4 \%$ - small, $28,1 \%$ - medium companies, and $12,5 \%$ were large corporations.

$92,2 \%$ of companies sold their products on regional market, $78,1 \%$ of them - on Polish market, and 45,3\% - on foreign market. Among the companies analysed there were manufacturers of well known brands, not only in the region and in the Polish market, but also on the foreign ones (mainly in the European Union). The analysed companies cooperate with partners in distribution channels in Lubelskie region, in Poland and also countries abroad.

The most $(73,4 \%)$ firms had put product innovations into practice during the last three years, with $65,6 \%$ firms applying innovative technology, $59,4 \%$ firms - innovations in management, and 46,7\% firms - new business processes. In quantitative terms, innovative solutions on a regional scale were dominant (made up $68,1 \%$ of all innovations), followed by innovative solutions on a national scale $(23,4 \%)$. During the analysed period the companies in question implemented as few as $8,5 \%$ of innovative solutions on an international scale. On average, each analysed company implemented $10(10,33)$ innovations during the analysed three year period. Such data indicate that companies increased their activities to ensure a more 
competitive nature of their innovations on the national and international arena. This new stance could be attributed to Poland's membership in the European Union.

The majority of innovative solutions implemented in companies resulted from in-house development projects. This clearly indicates that there is considerable potential in partnership cooperation in the area of innovation which has not as yet been utilised.

The performance of firms in innovation network should depend on the knowledge assets stock and their skill in organizing knowledge creation, exchange and using in innovation processes. Innovative assets of the companies are a result of their internal learning and external sources.

The analyzed companies cooperate with partners in innovation networks, at home and abroad. The following partners (at home and abroad) of the firms were taken into consideration in carried out research: firms in the same line of business, firms different line of business, high schools (universities, polytechnics), R\&D entities, regional and/or local authorities, innovation transfer institutions, scientific and technological parka, clusters, and also financial institutions.

The research results showed that all analyzed companies cooperated with partners during innovation processes execution. The majority $(95,4 \%)$ of companies cooperated with partners at home, and fewer $(43,6 \%)$ firms both home and abroad, and 4,6\% - only abroad. The capacity for assimilation of external knowledge depends on the company's internal capacity and how it structures its relations with partners in innovation networks. Most $(62,5 \%)$ firms cooperated during innovation process execution with firms in the same line of business at home, however $39 \%$ did so with firms from abroad. Fewer $(46,9 \%)$ firms cooperated with firms of different line of business at home, $15,6 \%$ - with the ones from abroad, and $34,4 \%$ firms cooperated with only home universities, polytechnics and fewer $(17,2 \%)-$ with R\&D entities at home, and very few $(1,6 \%)$ - abroad.

The companies demonstrated little activity in cooperating with the representatives of regional and/or local authorities, because with $15,6 \%$ of them doing it at home, and 1,6\% - abroad. Very few (4,7\%) companies cooperated with innovation transfer institutions at home and only 1,6\% abroad, and few $(3,1 \%)$ firms cooperated with domestic technology and science parks, and $(7,8 \%)$ - with clusters.

$23,4 \%$ analysed companies cooperated with firms from one other country, 9,4\% - with firms from 2 other countries, and 9,4\% - from 3 different countries, and only $1,6 \%$ - with firms from more than 10 countries.

The above data confirms that the biggest number of companies had viable innovation cooperation schemes with partners on the domestic market and fewer - on foreign markets. 
$56,3 \%$ of the companies carried out R\&D activity, and 37,5\% - carried out it on their own, $28,1 \%$ - only collaborated with other entities in this field, and 10,9\% - carried out this activity on their own and also with specialist firms outside. The companies carried out their R\&D activity largely on their own.

The cooperation of the companies with partners in innovation networks was highly evaluated. The total assessments of companies' effective cooperation with all partners, at home as well as abroad, was the highest $(68,3 \%$ opinions), effective - medium $(29,2 \%)$ and ineffective - small $(2,5 \%)$. The cooperation of the companies with partners at home was evaluated better (47,8\% opinions - effective, 26,1 - little effective, and 2,5\% - ineffective) than with partners at home $(20,5 \%$ opinions - effective, $3,1 \%$ - little effective, and no opinions - ineffective).

Partnership schemes were maintained in innovation networks by most $(87,9 \%)$ analyzed companies on the domestic market (with 603 partners, that is $87,9 \%$ of all 686 partners of the analyzed companies) and fewer - on the foreign market (with 83 partners, that is $12,1 \%$ of them). One analysed company cooperated on average - with 10 partners both home and abroad.

The respondents had the best opinion about cooperation with firms in the same line of business (30,4\% opinions - effective, $8,7 \%$ - little effective, and $1,2 \%$ - ineffective) and good opinion about cooperation with firms from a different line of business (18\% opinions - effective, 6,8\% little effective, and no opinions - ineffective). The collaboration with universities, polytechnics was assessed the most badly (only for $6,2 \%$ of firms this collaboration was effective, and for $6,8 \%$ - little effective, and $0,6 \%-$ ineffective). The efficiency of cooperation with R\&D entities $(5,6 \%$ opinions - effective, $1,2 \%$ - little effective, $0,6 \%$ - ineffective), and regional/local authority ( $4,3 \%$ opinions - effective, $2,5 \%$ - little effective, and no opinions - ineffective) was assessed more badly.

The cooperation with scientific and technological parks, clusters, innovation transfer institutions, was assessed as hardly effective. The collaboration of the firms with clusters, innovation transfer institutions and scientific-technological parks was evaluated badly (from 0,6 to $1,9 \%$ - opinions - effective, from 0,6 to $1,2 \%$ - little effective, and lack of opinions - ineffective).

Most companies assessed their cooperation in innovation networks with home and abroad partners favorably. The conclusion from this analysis is that the cooperation between the companies and their partners in innovation networks was effective and membership of Poland in EU was conducive to development of partner relationships during innovation processes execution. The respondents expected development of effective cooperation with many new partners in the future, in particular - with these forms of the 
innovation networks, which are now being created in Poland - clusters and science or technological parks.

The results of the study confirmed the validity of the working hypothesis proposed.

\section{CONCLUSIONS}

This paper was able to confirm that cooperative relationships are of high relevance for the development of innovative companies in the network. The results of the study indicate that entrepreneurs are interested in boosting participation of their companies in innovative processes in order to increase their cooperation with partners in the area of the innovation network.

The results of the studies confirmed innovative development of the analysed companies in the last years and a growing awareness of their employees on how significant interactions and relationships with partners during innovation process execution in the network were in providing organizations with a competitive edge on the market and in developing a knowledge-based economy in our country. The companies researched have reported an effective cooperation with their partners of innovation networks.

\section{LITERATURE}

Basadur M., Gelade G. A. (2006), The Role of Knowledge Management in the Innovation Process, "Creativity \& Innovation Management", Vol. 15, No. 1.

Chen Ch. (2008), Causal modeling of knowledge-based economy, "Management Decision", Vol. 46, No. 3.

Dilk Ch., Gleich R., Wald A. (2008), State and development of innovation network, "Management Decision", Vol. 46, No. 5.

Dolińska M. (2006), Kapitat intelektualny i innowacje, „Ekonomika i Organizacja Przedsiębiorstwa", Vol. 8, No. 679.

Dolińska M. (2009), Marketingowe i organizacyjne uwarunkowania zarzadzania wiedza $w$ procesie innowacji wdrażanych $w$ przedsiębiorstwie, Sprawozdanie merytoryczne - projekt badawczy własny nr 1 H02D 060 30, MNiSzW, Warszawa.

Dolińska M. (2010), Innowacje w gospodarce opartej na wiedzy, Polskie Wydawnictwo Ekonomiczne, Warszawa.

Halinen A., Törnroos J. A. (1998), The role of embeddedness in the evolution of business networks, "Scandinavian Journal of Management", Vol. 14, No. 3.

Pittway L., Robertson M., Munir K., Denyer D., Neely A. (2004), Networking and innovation: a systematic review of the evidence, "International Journal of Management Reviews", Vol. 5/6, No. 3\&4. 
Powell W.W. (2004), Critical Studies in Economic Institutions: Network, Edward Elgar, London.

Powell W.W., Grodal S. (2006), Networks of innovators, [in:] J. Fagerberg, D.C. Mowery, R.R. Nelson (eds.), The Oxford Handbook of Innovation, Oxford University Press, Oxford.

Pomykalski A. (2001), Zarzqdzanie innowacjami, Wydawnictwo Naukowe PWN, Warszawa. 
